\title{
KREATIVITAS MENGAJAR MAHASISWA PPL II JURUSAN PGMI FAKULTAS TARBIYAH DAN KEGURUAN UIN ANTASARI BANJARMASIN TAHUN 2015/2016
}

\author{
Siti Shalihah \\ Program Studi Pendidikan Guru Madrasah Ibtidaiyah \\ Universitas Islam Negeri Antasari \\ E-mail: sitishalihah75@gmail.com
}

\begin{abstract}
The study aims to determine the creativity of teaching students PPL II PGMI FTK UIN Antasari Year 2015/2016 and the factors that influence it. This type of research is field research (field research) with qualitative approach. The design used in this research is descriptive research. Objects in this research is the creativity of teaching students PPL II Faculty of Tarbiyah and Teacher Training Program PGMI Antasari Banjarmasin Year Ajisi 2015/2016. Subjects in this study were Students PPL II force 2012 Department of PGMI Faculty of Tarbiyah and Teacher Training UIN Antasari Banjarmasin located in MI Al Istiqamah, amounting to ten people. Techniques of data collection using observation, interviews, and documentation. Data analysis technique used is descriptive qualitative. The result of the research shows that the creativity of teaching students of PPL II UIN can be seen from the variation of active learning strategy and the variation of media used. While for the source of learning, PPL II students are still many who only use learning resources in the form of textbooks. Factors that affect the creativity of teaching students PPL II, including teacher candidate factors consisting of educational background and learning experience, facilities and learning resources, as well as conductive environmental conditions.
\end{abstract}

Key Words: creativity; teaching practice; college student

\begin{abstract}
ABSTRAK
Penelitian ini bertujuan untuk mengetahui kreativias mengajar mahasiswa PPL II Jurusan PGMI FTK UIN Antasari tahun 2015/2016 dan faktor-faktor yang mempengaruhinya. Jenis penelitian ini adalah penelitian lapangan (field research) dengan pendekatan kualitatif. Desain yang digunakan dalam penelitian ini adalah penelitian deskriptif. Objek dalam penelitian ini adalah kreativitas mengajar mahasiswa PPL II Fakultas Tarbiyah dan Keguruan Jurusan PGMI UIN Antasari Banjarmasin Tahun Ajaran 2015/2016. Subjek dalam penelitian ini adalah Mahasiswa PPL II angkatan 2012 Jurusan PGMI Fakultas Tarbiyah dan Keguruan UIN Antasari Banjarmasin yang berlokasi di MI Al Istiqamah yang berjumlah sepuluh orang. Teknik pengumpulan data menggunakan observasi, wawancara, dan dokumentasi. Teknik analisis data yang digunakan adalah deskriptif kualitatif. Hasil penelitian menunjukkan kreativitas mengajar mahasiswa PPL II UIN dapat dilihat dari bervariasinya strategi pembelajaran aktif dan variasi media yang digunakan. Sementara untuk sumber belajar, mahasiswa PPL II masih banyak yang hanya menggunakan sumber belajar berupa buku pelajaran. Faktor-faktor yang mempengaruhi kreativitas mengajar mahasiswa PPL II, diantaranya faktor calon guru yang terdiri dari latar belakang pendidikan dan pengalaman belajar, fasilitas dan sumber belajar, serta kondisi lingkungan yang kondusif.
\end{abstract}

Kata Kunci: kreativitas; praktek mengajar; mahasiswa

\section{PENDAHULUAN}

Proses belajar mengajar merupakan suatu proses yang mengandung rangkaian perbuatan guru dan siswa atas hubungan timbal balik yang berlangsung dalam situasi edukatif untuk mencapai tujuan tertentu. Guru berperan utama dalam interaksi edukatif dan berfungsi sebagai 
sumber belajar dan kerapkali mendominasi proses transformasi nilai pengetahuan dan lainlainnya kepada peserta didik. Pekerjaan menjadi guru merupakan profesi, artinya suatu pekerjaan tersendiri yang menentukan keahlian sebagai guru, dapat dilaksanakan oleh setiap orang, namun tidak berarti semua orang memiliki profesi keguruan (Asril, 2007).

Guru merupakan ujung tombak berlangsungnya kegiatan pembelajaran, sehingga memiliki peran dan fungsi penting sebagai pendidik dan kerapkali mendominasi proses transformasi nilai ilmu pengetahuan dan lain-lainnya kepada peserta didik. Kegagalan atau keberhasilan kegiatan belajar mengajar sangat bergantung pada seni dan kreativitas guru dalam menyampaikan pelajaran. Kemampuan yang dimiliki oleh guru akan menghasilkan pembentukan kualitas peserta didiknya. Meskipun guru memiliki penguasaan terhadap bahan ajar atau materi pelajaran yang diberikan sudah cukup memadai, tetapi kurang mampu mengemasnya dalam pembelajaran, miskin kreatif, monoton, membosankan, kurang menarik, dan sebagainya, akhirnya berujung pada pencapaian hasil pendidikan yang kurang memadai (Agung, 2010).

Dari hasil pengamatan yang penulis lakukan pada saat melaksanakan tugas sebagai supervisor PPL II di MIS Sullamut Taufik selama dua tahun berturut (Tahun 2013 dan 2014), mahasiswa PPL II saat melaksanakan pembelajaran di kelas masih banyak yang tidak menggunakan media pembelajaran dan kurang memanfaatkan sumber belajar yang ada di sekolah. Berdasarkan realita yang ada, kiranya perlu adanya pengembangan gagasan/ide dan perilaku pembelajaran calon guru yang kreatif menjadi faktor penting dalam mencapai hasil pendidikan yang memadai. Kreativitas guru dapat menciptakan pembelajaran yang lebih aktif, dinamis dan tidak monoton, sehingga siswa akan lebih bersemangat dalam mengikuti pelajaran dikelas. Kreativitas guru berhubungan dengan merancang dan mempersiapkan bahan ajar/materi pelajaran, mengelola kelas, menggunakan metode yang variatif, memanfaatkan media pembelajaran, sampai dengan mengembangkan instrumen evaluasi.

Fakultas Tarbiyah dan Keguruan (FTK) Universitas Islam Negeri Antasari Banjarmasin merupakan sebuah Lembaga Pendidikan Tenaga Kependidikan (LPTK) yang mempunyai misi dan tugas menyiapkan serta menghasilkan guru atau tenaga kependidikan yang memiliki kompetensi pedagogik, professional, kepribadian dan sosial. Salah satu cara untuk mencapai kompetensi dan profil lulusan tersebut adalah dengan meningkatkan kemampuan dasar mengajar (teaching learning), keterampilan dalam mengelola PBM dan pengelolaan kelas sebagai upaya untuk meningkatkan kesiapan mengajar mahasiswa sebagai calon guru, baik secara teoritis maupun praktis melalui mata kuliah penunjang seperti mata kuliah PPL I yang diselenggarakan di laboratorium micro teaching dan PPL II yang langsung diselenggarakan di sekolah. Materi pelajaran dan aplikasi nilai-nilai yang terkandung dalam materi pelajaran senantiasa berkembang sejalan dengan kebutuhan masyarakatnya. Agar senantiasa dapat menyesuaikan dan mengarahkan perkembangan, maka guru diharapkan memperbaharui dan meningkatkan ilmu pengetahuan yang dipelajari secara terus menerus.

Dalam hal ini, mahasiwa PPL harus memiliki pandangan yang lebih luas dan kreativitas yang tinggi. Kreativitas yang dimaksud yaitu penggunaan strategi dan metode, pemakaian media dan pemanfaatan sumber belajar.Melalui kreativitas diharapkan pelaksanaan aktivitas pembelajaran lebih bersifat aktif, dinamis, menggairahkan dan pada akhirnya mengarah pada pencapaian kualitas hasil yang diharapkan. Berdasarkan pemaparan tersebut, maka perlu diadakan penelitian yang bertujuan untuk mengetahui kreativias mengajar mahasiswa PPL II Jurusan PGMI FTK UIN Antasari tahun 2015/2016 dan faktor-faktor yang mempengaruhinya.

\section{Kreativitas Mengajar}

Kreativitas merupakan potensi yang dimiliki setiap manusia dan bukan yang diterima dari luar individu. Dikutip dari berbagai sumber, berikut ini dikemukakan beberapa pengertian kreativitas, yaitu: 
a. Menurut Slameto (2003), "Kreativitas itu bukanlah penemuan yang belum pernah diketahui orang sebelumnya, melainkan bahwa produk kreativitas itu merupakan sesuatu yang baru bagi diri sendiri dan tidak harus merupakan sesuatu yang baru bagi orang lain atau dunia pada umumnya, misalnya seorang guru menciptakan metode mengajar dengan diskusi yang belum pernah ia pakai."

b. Menurut Talajan (2012), "Kreativitas adalah mengacu pada kemampuan yang khas dari orang-orang kreatif."

Berdasarkan beberapa pendapat tersebut dapat disimpulkan bahwa kreativitas merupakan kemampuan seseorang untuk menghasilkan sesuatu yang baru dengan menggunakan unsur yang telah ada, baik itu dengan mengembangkan ataupun mengkombinasikannya menjadi sesuatu yang baru.

Manusia kreatif, apabila dibandingkan dengan manusia biasa menunjukkan ciri-ciri yang berbeda dalam motivasi, intelektual, dan kepribadian. Baron mengungkapkan hasil studinya bahwa individu yang kreatif memiliki ciri-ciri sebagai berikut:

a. Lebih menunjukkan sikap dewasa secara emosional dan peka dalam menangkap masalah dari suatu situasi.

b. Dapat memenuhi kebutuhannya sendiri.

c. Tidak bergantung pada orang lain dan percaya pada diri sendiri

d. Mampu menguasai dirinya sendiri.

e. Penuh keberanian yang bermakna

f. Panjang akal. (Talajan, 2012)

Dari beberapa ciri di atas maka penulis dapat menyimpulkan bahwa kepribadian orang kreatif dapat diketahui dari sifat-sifat yang muncul atau tampak pada tindakan dan pekerjaan. Kreativitas dapat diterapkan dalam kegiatan belajar mengajar yang disebut dengan pembelajaran kreatif maksudnya pembelajaran yang membuat pemikiran yang dapat disampaikan kemudian digunakan dalam kehidupan. Pembelajaran tersebut dapat disebut belajar yang sukses, yakni mengajar hendaknya dinilai berdasarkan hasil-hasil yang mantap atau tahan lama dan dapat digunakan peserta didik dalam kehidupannya kelak.

\section{Pengembangan Kreativitas Mengajar}

Dalam melakukan persiapan mengajar guru tidak cukup berbekal bahan ajar atau materi pelajaran yang akan disampaikan kepada peserta didiknya, melainkan juga pengelolaan kelas, metode dan media yang digunakan, sampai dengan alat evaluasi yang akan diterapkan dalam mengetahui hasil pembelajaran. Berikut upaya-upaya mengembangkan kreativitas mengajar guru:

a. Merancang dan menyiapkan bahan ajar/materi pelajaran

b. Merancang pengelolaan kelas

c. Pemanfaatan waktu

d. Penggunaan strategi pembelajaran

3. Karakteristik Pengajar Kreatif

Dalam bidang pendidikan, pemegang kunci dalam pengembangan daya kreativitas anak adalah pengajar (guru). Seorang pengajar yang ingin mengembangkan kreativitas pada anak didiknya, harus terlebih dahulu kreatif. Sebagaimana pendapat Cece Wijaya yang menyebutkan bahwa guru sebagai pendidik atau pengajar merupakan penentu kesuksesan dalam pendidikan. Oleh sebab itu, guru dituntut untuk mengembangkan kreativitasnya dalam proses belajar mengajar. Guru kreatif selalu mencari cara bagaimana agar proses belajar mengajar mencapai tujuan, serta berusaha menyesuaikan pola-pola tingkah lakunya dalam mengajar dengan tuntutan pencapaian tujuan, dengan mengembangkan faktor situasi kondisi belajar siswa.

Kreativitas ini memungkinkan guru bersangkutan menemukan bentuk mengajar yang sesuai, agar siswa dapat belajar secara efektif dan efisien. Menurut Brown, guru-guru kreatif 
yakni yang melaksanakan pembelajaran dengan mengoptimalkan ilmu dan keahliannya disebut dengan Teacher Scholar. Menurutnya, jika pembelajaran dilakukan dengan baik, hakikatnya adalah kreatif. Lebih lanjut Brown (dalam Asmani, 2010) merumuskan ciri-ciri seorang Teacher Scholar adalah sebagai berikut:

a. Mempunyai keingintahuan yang tinggi, selalu mempelajari atau mencari tahu tentang segala sesuatu yang masih belum jelas dipahaminya.

b. Setiap hal dianalisis terlebih dahulu, kemudian disaring, dikualifikasi untuk ditelaah dan dimengerti, lalu diendapkan dalam "gudang pengetahuannya".

c. Memiliki intuisi yang tajam, yaitu kemampuan bawah sadar yang menghubungkan gagasan-gagasan lama guna membentuk ide-ide baru.

d. Memiliki disiplin diri yang tinggi, Mengandung arti bahwa guru yang kreatif itu memiliki kemampuan untuk melakukan pertimbangan-pertimbangan sebelum mengambil keputusan.

e. Tidak akan pula dengan hasil sementara. Guru kreatif tidak akan menerima begitu saja setiap hasil yang belum memuaskannya.

f. Suka melakukan introspeksi. Sifat ini mengandung kemampuan untuk menaruh kepercayaan terhadap gagasan-gagasan orang lain.

g. Mempunyai kepribadian yang kuat, tidak mudah diberi instruksi tanpa pemikiran.

Ciri-ciri atau karakteristik guru kreatif juga dikemukakan oleh Mark Sund (dalam Talajan 2012), yaitu:

a. Guru kreatif memiliki rasa ingin tahu yang sangat besar, sehingga mendorong seorang guru mengetahui hal-hal baru yang berkaitan dengan aktivitas dan pekerjaannya sebagai guru.

b. Guru kreatif memiliki sikap yang ekstrovert atau bersikap lebih terbuka dalam menerima hal-hal baru dan selalu ingin mencoba untuk melakukannya, dan dapat menerima masukan dan saran dari siapapun yang berkaitan dengan pekerjaannya, dan menganggap bahwa halhal baru tersebut dapat menjadi pengamalan dan pelajaran baru bagi dirinya.

c. Guru kreatif biasanya tidak kehilangan akal dalam menghadapi masalah tertentu, sehingga sangat kreatif dan "panjang akal" untuk menemukan solusi diri setiap masalah yang muncul. Dan bahkan lebih cenderung menyukai tugas yang berat dan sulit karena akan menimbulkan rasa kepuasan tersendiri setelah mampu menyelesaikan tugas tersebut.

d. Guru kreatif sangat termotivasi untuk menemukan hal-hal baru baik melalui observasi, pengalaman dan pengamatan langsung dan melalui kegiatan-kegiatan penelitian. Hal ini disebabkan karena guru kreatif cenderung mencari jawaban yang luas dan memuaskan secara ilmiah.

\section{Pentingnya Kreativitas Mengajar}

Secara umum kreativitas guru memiliki fungsi utama yaitu membantu menyelesaikan pekerjaannya dengan cepat dan efisien. Namun menurut Noor Rachman Hadjan (dalam Talajan 2012) fungsi tersebut dapat dispesifikasikan menjadi beberapa macam, yaitu:

a. Kreativitas guru berguna bagi peningkatan minat peserta didik terhadap mata pelajaran.

b. Kreativitas guru berguna dalam mentransfer informasi lebih utuh.

c. Kreativitas guru berguna untuk merangsang peserta didik berfikir ilmiah.

d. Produk kreativitas guru akan merangsang aktifitas peserta didik.

\section{Faktor-Faktor yang Mempengaruhi Kreativitas Mengajar}

Tumbuhnya kreativitas mengajar dipengaruhi oleh beberapa hal, yaitu:

\section{a. Faktor Guru}

Guru merupakan faktor yang sangat besar pengaruhnya, bahkan sangat menentukan berhasil tidaknya peserta didik dalam belajar. Tugas guru tidak hanya menyampaikan informasi kepada peserta didik, tetapi harus kreatif memberikan layanan dan kemudahan 
belajar kepada seluruh peserta didik, agar mereka dapat belajar dalam suasana yang menyenangkan, gembira, penuh semangat, tidak cemas, dan berani mengemukakan pendapat secara terbuka.

\section{b. Faktor Jumlah Peserta didik}

Menurut Peraturan Menteri Pendidikan dan Kebudayaan tahun 2013 disyaratkan bahwa maksimal jumlah peserta didik per-rombel (rombongan belajar) untuk SD adalah 32 siswa dan minimal adalah 20 siswa. Hal ini disebabkan karena kondisi siswa dalam belajar sangat berpengaruh terhadap kemampuan guru dalam menciptakan suasana belajar dan menggunakan metode yang tepat, terutama jika jumlah siswa yang diajarkan sangat banyak.Hal ini disebabkan karena setiap siswa memiliki tingkat pemahaman yang berbeda dalam menangkap pelajaran. Selain itu kemampuan siswa dalam belajar juga mempengaruhi proses belajar.

\section{c. Faktor Sumber Belajar}

Sumber belajar yang memadai merupakan salah satu faktor penunjangkreativitas mengajar seorang guru. Fasilitas dan sumber belajar itu antara lain laboratorium, pusat sumber belajar, dan perpustakaan, serta tenaga pengelola dan peningkatan kemampuan pengelolaannya. Fasilitas dan sumber belajar ini perlu didayagunakan seoptimal mungkin, dipelihara, dan disimpan dengan sebaik-baiknya. Kreativitas guru dan peserta didik perlu senantiasa ditingkatkan untuk membuat dan mengembangkan alat-alat pembelajaran serta alat peraga lain yang berguna bagi peningkatan kualitas pembelajaran. Pendayaguanaan fasilitas dan sumber belajar perlu dikaitkan dengan kompetensi ingin dicapai dalam proses pembelajaran. Dengan kata lain, fasilitas dan sumber belajar dipilih dan digunakan dalam proses belajar mengajar apabila sesuai dan menunjang tercapainya kompetensi (Mulyasa, 2013).

\section{e. Lingkungan Sekolah}

Lingkungan sekolah yang nyaman, aman, dan tertib, optimisme dan harapan yang tinggi dari seluruh warga sekolah, kebersihan sekolah, serta kegiatan-kegiatan yang terpusat pada peserta didik merupakan iklim yang dapat membangkitkan gairah dan semangat belajar. Iklim belajar yang kondusif merupakan tulang punggung dan faktor pendorong kreativitas mengajar yang dapat memberikan daya tarik tersendiri bagi proses belajar, sebaliknya iklim belajar yang kurang menyenangkan akan menimbulkan kejenuhan dan rasa bosan. Iklim belajar yang kondusif akademik harus ditunjang oleh berbagai fasilitas belajar yang menyenangkan seperti sarana laboratorium, pengaturan lingkungan, penampilan dan sikap guru, hubungan yang harmonis antara peserta didik dan guru dan diantara peserta didik itu sendiri, serta penataan organisasi dan bahan pembelajaran secara tepat, sesuai dengan kemampuan dan perkembangan peserta didik (Mulyasa, 2013).

\section{Kegiatan PPL II Program Studi PGMI}

Praktik Pengalaman Lapangan (PPL) II Prodi PGMI adalah tahap kegiatan latihan mengajar dan latihan tugas administrasi keguruan yang dilaksanakan secara terintegrasi, dan dalam situasi nyata di madrasah/sekolah latihan baik secara terbimbing ataupun mandiri. Tujuan umum dari kegiatan PPL II adalah untuk melatih mahasiswa sebagai calon guru agar memiliki kemampuan mempraktikkan kinerja dalam situasi kegiatan nyata, dalam hal mengajar dan tugas-tugas keguruan lainnya pada jurusan PGMI. Sedangkan tujuan khusus dari pelaksanaan PPL II adalah sebagai berikut :

a. Mampu menguasai berbagai keterampilan dasar mengajar.

b. Mampu menerapkan berbagai kemampuan mengajar secara utuh dan terpadu dalam situasi nyata.

c. Mampu menguasai bahan ajar dalam bidang pendidikan.

d. Mampu membuat dan melaksanakan administrasi keguruan dalam bidang Pendidikan Guru Madrasah Ibtidaiyah. 
e. Mampu mengembangkan aspek pribadi dan social di lingkungan sekolah.

f. Mampu merefleksi nilai edukatif dari pengetahuan dan pengalamannya selama praktikum.

Setiap mahasiswa yang akan mengikuti kegiatan PPL II sebelumnya diberikan bekal dasar berupa sejumlah pengetahuan dan pengalaman yang harus dimiliki sebagai calon guru. Bekal dasar ini pada dasarnya adalah prasyarat-prasyarat dalam bentuk mata kuliah yang harus ditempuh terlebih dahulu oleh mahasiswa sebelum memprogramkan PPL, yang terdiri dari bekal dasar umum dan khusus atau yang disebut prasyarat umum dan prasyarat khusus.

Beberapa hal yang terkait dengan penyelenggaraan implementasi konkrit di lapangan pada PPL II jurusan Pendidikan Guru Madrasah Ibtidaiyah, dapat dijabarkan sebagai berikut:

a) PPL II untuk mahasiswa Fakultas Tarbiyah IAIN Antasari Banjarmasin dilaksanakan di madrasah/sekolah tempat latihan, baik negeri atau swasta di lingkungan Kotamadya Banjarmasin dan Kabupaten Banjar.

b) PPL II diselenggarakan dalam rentang waktu selama 2 sampai 2.5 bulan ( 8 - 12 minggu). Selama waktu tersebut, praktikan berada di madrasah/sekolah latihan selama tiga hari dalam satu minggu (magang) sesuai dengan jam kerja madrasah/sekolah, dengan frekuensi latihan 10 kali latihan praktik mengajar dan dua kali ujian praktik mengajar, sehingga berjumlah 12 kali praktik mengajar. Bila diperlukan (misalnya karena mahasiswa yang bersangkutan belum memperoleh nilai lulus, karena mahasiswa sakit atau halangan lainnya) atas kesepakatan guru pamong dan supervisor, waktu tersebut dapat diperpanjang.

c) Pada Minggu Pertama di madrasah/sekolah latihan, mahasiswa melakukan observasi lapangan, dan dilanjutkan secara bersama-sama dengan guru pamong membuat rencana kegiatan latihan untuk dilaksanakan selama PPL II.

d) Bahan/Tugas praktik ditetapkan oleh guru pamong. Mahasiswa harus mengambil tugas ini paling lambat tiga hari sebelum praktik dilaksanakan.

e) Mahasiswa selanjutnya membuat perencanaan pembelajaran atau persiapan mengajar secara lengkap sesuai dengan ketentuan yang berlaku di madrasah/ sekolah tersebut atau sesuai dengan permintaan guru pamong yang bersangkutan.

f) Konsep perencanaan pembelajaran tersebut harus dikonsultasikan terlebih dahulu kepada guru pamong, selanjutnya harus ditandatangani oleh guru pamong sebelum dilaksanakan di kelas.

g) Khusus untuk perencanaan pembelajaran dalam rangka ujian praktik (middle dan final). Konsepnya harus dikonsultasikan dan ditandatangani lebih dahulu oleh guru pamong dan supervisor.

h) Bagi mahasiswa yang selama PPL II masih harus mengikuti perkuliahan di kampus, harus dapat menyusun jadwal agar waktu selama tiga hari yang dipersiapkan untuk PPL II tidak bertabrakan.

i) Mahasiswa yang karena sesuatu hal tidak dapat hadir ke madrasah/sekoiah tempat latihan harus memberi kabar, yang disertai dengan dokumen pendukung yang sah. Dan setiap mahasiswa harus mengisi absensi di madrasah/ sekolah tempat latihan, dan mengisi Jurnal Kegiatan Harian untuk dilampirkan dalam laporan.

\section{METODE PENELITIAN}

Jenis penelitian ini adalah penelitian lapangan (field research) dengan pendekatan kualitatif yang berbentuk paparan berdasarkan data alamiah di lapangan dengan apa adanya serta penarikan kesimpulan yang bersifat induktif. Desain yang digunakan dalam penelitian ini adalah penelitian deskriptif, yaitu suatu penelitian yang bertujuan untuk membuat deskripsi, gambaran atau lukisan yang sistematis, faktual dan akurat mengenai fakta-fakta, sifat-sifat serta hubungan antar fenomena yang diselidiki (Nazir, 2011). 
Objek dalam penelitian ini adalah kreativitas mengajar mahasiswa PPL II Fakultas Tarbiyah dan Keguruan Jurusan PGMI UIN Antasari Banjarmasin Tahun Ajatan 2015/2016. Subjek dalam penelitian ini adalah Mahasiswa PPL II angkatan 2012 Jurusan PGMI Fakultas Tarbiyah dan Keguruan UIN Antasari Banjarmasin yang berlokasi di MI Al Istiqamah yang berjumlah sepuluh orang. MI Al Istiqamah dipilih dalam penelitian ini karena penulis bertugas sebagai supervisor pada tahun 2015 di madrasah tersebut.

Data Pokok dalam penelitian ini adalah : kreativitas mengajar mahasiswa PPL II Fakultas Tarbiyah dan Keguruan Jurusan PGMI UIN Antasari Banjarmasin Tahun 2015/2016 dan faktor-faktor yang mempengaruhi kreativitas mengajar. Sumber data dalam penelitian terdiri dari berbagai sumber, yaitu:

a. Responden dalam penelitian ini adalah mahasiswa jurusan PGMI angkatan 2012 yang sedang PPL II MIS Al-Istiqamah Banjarmasin.

b. Informan dalam penelitian ini adalah Kepala Sekolah, Staf Tata Usaha dan Dewan Guru MIS Al-Istiqamah Banjarmasin.

c. Dokumen, yaitu semua catatan ataupun arsip yang memuat data-data atau informasi yang mendukung dalam penelitian ini.

Pengumpulan data dalam penelitian ini menggunakan beberapa teknik, yaitu observasi, wawancara, dan dokomentasi. Teknik analisis data yang digunakan adalah deskriptif kualitatif, melalui tahapan : reduksi, display dan verifikasi.Pada tahap reduksi diupayakan menemukan hal-hal pokok tentang obyek penelitian, yaitu kreativitas mengajar mahasiswa PPL II Fakultas Tarbiyah dan Keguruan Jurusan PGMI UIN Antasari Banjarmasin Tahun 2015/2016.

\section{HASIL PENELITIAN DAN PEMBAHASAN}

\section{A. Hasil Penelitian}

Lokasi yang digunakan dalam penelitian ini adalah MIS Al-Istiqamah yang beralamat di Jalan Pekapuran Raya RT. 42 No. 1, Kelurahan Pemurus Baru, Kecamatan Banjarmasin Selatan, Kota Banjarmasin. Berdasarkan rumusan masalah dalam penelitian ini tentang kreativitas mengajar mahasiswa PPL II Jurusan PGMI Fakultas Tarbiyah dan Keguruan Tahun akademik 2015/2016 dan faktor-faktor yang mempengaruhinya, maka data yang disajikan menjadi dua bagian, yaitu :

\section{Kreativitas Mengajar Mahasiswa PPL II Jurusan PGMI}

Hasil penelitian tentang kreativitas mengajar di kelas berkaitan erat dengan pemahaman kreativitas itu sendiri.Kreativitas menunjukkan pemahaman yang sangat beragam dari beberapa mahasiswa yang menjadi obyek dalam penelitian ini. Berdasarkan hasil wawancara yang dilakukan dengan beberapa mahasiwa PPL II MI Al-Istiqamah Banjarmasin memberikan hasil bahwa kreativitas memiliki arti yang beragam, antara lain kreativitas itu memunculkan ide yang baru, segala sesuatu yang berbeda dengan lainnya, dan mengadopsi yang telah ada menjadi sesuatu yang baru, sehingga kreativitas yang muncul dalam kegiatan PPL II dapat dikelompokkan menjadi :

\section{a. Kreativitas dalam Penggunaan Strategi/Metode Pembelajaran}

Berdasarkan hasil observasi yang penulis lakukan, strategi/metode pembelajaran yang digunakan oleh mahasiwa PPL II di MIS Al-Istiqamah, yaitu:

\section{1) Fathiyah}

Fathiyah menggunakan Strategi pembelajaran aktif Crossword Puzzle tanggal 19 September 2015, pada mata pelajaran Sejarah Kebudayaan Islam kelas V ${ }^{a}$ semester I, materi tentang kaum Muhajirin dan Anshar. Berikut ini rangkaian kegiatan strategi Crossword Puzzle: Guru menjelaskan materi pelajaran mengenai kaum Muhajirin dan kaum Anshar; lalu meminta peserta didik untuk menulis materi pelajaran mengenai kaum Muhajirin dan kaum Anshar; membagikan teka-teki silang kepada setiap peserta didik; peserta didik mencari 
jawaban dari teka-teki yang telah disediakan; peserta didik maju kedepan kelas untuk menyampaikan hasil tugasnya; guru melakukan tanya jawab dengan peserta didik mengenai materi kaum Muhajirin dan kaum Anshar yang belum dipahami; guru mengklarifikasi hasil kegiatan peserta didik.

\section{2) Annisa Widya Anggraeni}

Strategi pembelajaran koperatif Make a Match digunakan oleh Annisa dalam pembelajaran Akidah Akhlah kelas $\mathrm{V}^{\mathrm{a}}$ Semester I pada tanggal 08 Oktober 2015, dengan materi pelajaran asmaul husna Al-Mugni. Rangkaian kegiatannya yaitu: guru memutarkan video pembelajaran yang berkaitan asmaul husna Al-Mugni; penjelasan tentang materi; meminta peserta didik untuk membuat kelompok; lalu memberikan teks yang di acak untuk dipasangkan dengan gambar. Strategi pembelajaran koperatif Index Card Match digunakan oleh Annisa pada kegiatan final test yang dilaksanakan pada tanggal 15 Oktober 2015 dengan mata pelajaran Matematika kelas $\mathrm{V}^{\mathrm{a}}$ semester I dengan materi pengukuran waktu, jarak, dan kecepatan dalam pemecahan masalah. Berikut rangkaian kegiatan dengan menggunakan strategi Index Card Match: guru menjelaskan serta mendemonstrasikan materi pelajaran mengenai menentukan tanda waktu menggunakan rotasi 24 jam dengan alat peraga; membagi siswa menjadi beberapa kelompok, dan membagikan lembar kerja kepada masing-masing kelompok tersebut; kemudian setiap kelompok memasangkan kartu/ gambar yang telah disediakan.

\section{3) Rahma Zuraida}

Rahma Zuraida menggunakan strategi pembelajaran aktif The Power of Two pada tanggal 18 September 2015 pada mata pelajaran Fikih kelas IV $^{\mathrm{b}}$, dengan materi tentang orang-orang yang berhak menerima zakat fitrah. Berikut ini langkah-langkah kegiatannya: peserta didik diminta untuk membaca materi pelajaran yang ada di dalam buku paket; kemudian menyimak penjelasan guru dan mengamati gambar orang-orang yang berhak menerima zakat fitrah; membagi peserta didik dua orang setiap kelompoknya; lalu memberikan sebuah pertanyaan kepada masing-masing kelompok; setiap kelompok mendiskusikan jawabannya; kemudian diminta untuk mempresentasikannya di depan kelas.

Rahma Zuraida juga menggunakan strategi pembelajaran aktif Role Play pada tanggal 07 Oktober 2015, pada mata pelajaran Fikih kelas $\mathrm{IV}^{\mathrm{b}}$ semester I, mengenai tata cara zakat fitrah. Berikut ini rangkaian kegiatannya : peserta didik membaca materi tentang tata cara memberikan zakat fitrah; guru menjelaskan dan memberikan penguatan tentang materi zakat fitrah; guru mempraktikkan cara menakar beras dan tata cara memberikan zakat fitrah; peserta didik dibagi menjadi empat kelompok besar; setiap kelompok memilih 3 orang perwakilan untuk melaksanakan simulasi tata cara memberikan zakat fitrah; lalu peserta didik yang lain menanggapi hasil presentasi.

\section{4) Elma}

Strategi pembelajaran aktif Talking Stick digunakan oleh Elma pada tanggal 12 Oktober 2015, dengan mata pelajaran Fikih kelas $\mathrm{V}^{\mathrm{c}}$ semester I tentang manfaat makanan dan minuman halal dan akibat makanan dan minuman haram. Rangkaian kegiatan strategi Talking Stick ini adalah : peserta didik diminta untuk membaca materi yang ada di power point kemudian menyimak penjelasan yang disampaikan oleh guru; peserta didik membuat lingkaran besar dan menyanyikan beberapa buah lagu sambil memberikan stick(spidol) kepada teman di sampingnya; saat lagu dihentikan dan yang terakhir memegang stick (spidol) maka dia yang akan mendapatkan pertanyaan dari guru.

\section{5) Ainiah}

Ainiah menggunakan strategi aktif Everyone is A Teacher Here pada tanggal 17 Oktober 2015, mata pelajaran IPA kelas IV materi tentang bagian-bagian telinga dan cara merawatnya. Berikut rangkaian kegiatannya : guru membagikan bahan ajar kepada peserta didik dan memintanya untuk membaca secara seksama; memberikan secarik kertas kepada 
seluruh peserta didik dan meminta mereka untuk menuliskan satu pertanyaan tentang materi pelajaran yang sudah dipelajari; meminta peserta didik untuk mengumpulkan kertas, lalu kertas tersebut diacak dan dibagikan lagi kepada peserta didik; peserta didik secara sukarela diminta untuk membacakan pertanyaan dan memberikan jawaban terhadap pertanyaan tersebut.

\section{6) Halimatus Sa'diah}

Halimatus Sa'diah menggunakan strategi Contextual Teaching and Learning (CTL) pada tanggal 21 September 2015, dengan mata pelajaran Ilmu Pengetahuan Sosial kelas III ${ }^{\mathrm{a}}$ semester I. Materi pembelajaran yang disampaikan yaitu mengenai denah dan peta. Berikut ini rangkaian kegiatannya : peserta didik diminta membuka buku LKS dan membaca materi yang akan dipelajari; guru menjelaskan tentang materi yang dipelajari; lalu peserta didik menuliskan materi pelajaran; peserta didik diminta membuat denah rumah mereka masingmasing (menuju ke sekolah).

Halimatus Sa'diah juga menggunakan strategi Ekspositori pada tanggal 28 September 2015, dengan mata pelajaran Akidah Akhlak kelas III $^{\mathrm{a}}$ semester I dengan materi akhlak terpuji, dengan rangkaian kegiatan sebagai berikut : peserta didik mengamati video yang berjudul kisah nabi ismail dan akhlak terpuji (Rendah Hati, Santun, Ikhlas, Dermawan); guru menanyakan pendapat peserta didik tentang video yang sudah di tampilkan; guru menanyakan kepada peserta didik tentang materi yang belum dipahami; selanjutnya guru membagikan kertas kepada peserta didik; peserta didik diminta menceritakan kembali hal-hal apa saja yang mereka dapat setelah menonton video kisah nabi ismail dan akhlak terpuji (Rendah Hati, Santun, Ikhlas, Dermawan).

\section{7) Moh. Muchran}

Moh. Muchran menggunakan strategi pembelajaran aktif Card Short pada tanggal 06 Oktober 2015, mata pelajaran Ilmu Pengetahuan Sosial kelas III ${ }^{\mathrm{a}}$ semester I, dengan materi memelihara lingkungan alam dan buatan. Rangkaian kegiatan strategi Card Short sebagai berikut: guru menjelaskan materi pelajaran dan memberikan pertanyaan-pertanyaan singkat terkait dengan materi; lalu guru membagikan potongan-potangan kartu bergambar dan siswa di minta menjawabnya; siswa secara berpasang-pasangan menjawab soal-soal tersebut dan menempelkannya di karton yang telah disedian di papan tulis.

\section{8) Haryati}

Haryati menggunakan strategi Ekspositori pada tanggal 30 September 2015 pada mata pelajaran Ilmu Pengetahuan Alam kelas $\mathrm{II}^{\mathrm{b}}$ semester I tentang pertumbuhan hewan dan tumbuhan, dengan langkah-langkah : guru menyampaikan materi pelajaran; lalu memberikan kesempatan kepada peserta didik untuk menanyakan materi yang belum dimengerti; lalu membagi peserta didik menjadi lima kelompok; tiap kelompok mendapatkan bahan praktik seperti gelas plastik, kapas dan biji kacang hijau; selanjutnya guru mendemonstrasikan cara menanam biji kacang hijau pada media kapas, dan siswa mengikuti; guru meminta siswa untuk mengamati pertumbuhan biji kacang hijau tesebut selama satu minggu.

\section{9) Amalia Sholeha}

Amalia Sholeha menggunakan strategi Modeling the way pada tanggal 06 Oktober 2015, mata pelajaran Akidah Akhlak kelas II ${ }^{\mathrm{b}}$ semester I tentang sholat lima waktu, dengan rangkaian kegiatan sebagai berikut : guru membuat peta konsep di papan tulis dan meminta peserta didik untuk memperhatikan; guru menjelaskan materi dan memberikan pertanyaanpertanyaan singkat yang berkaitan dengan sholat lima waktu; peserta didik diminta untuk berbaris di depan kelas dan diarahkan untuk bersusun bershaf laki-laki di depan dan perempuan di belakang; guru menunjuk salah satu peserta didik untuk menjadi model dan menirukan gerakan shalat yang di bimbing oleh guru; yang lainnya mengikuti gerakan model tersebut; selanjutnya peserta didik dibagi menjadi beberapa kelompok dan guru membagi puzzle gerakan-gerakan sholat untuk diselesaikan secara bersama-sama. 
Strategi pembelajaran koperatif Make a Match digunakan oleh Amalia Sholeha pada tanggal 22 Oktober 2015 pada mata pelajaran Ilmu Pengetahuan Alam kelas II $^{\mathrm{b}}$ semester I, materi tempat hidup makhluk hidup, dengan rangkaian kegiatan sebagai berikut: guru menyampaikan materi; lalu menanyakan kepada peserta didik mengenai materi yang belum dipahami; guru menempelkan sebuah gambar berupa tempat-tempat makhuk hidup; lalu membagikan gambar-gambar hewan seperti singa, kura-kura, ikan kepada setiap peserta didik; peserta didik diminta untuk menempelkan gambar-gambar hewan sesuai dengan tempat makhluk hidupnya.

\section{0) Muhammad Rahmatullah}

M.Rahmatullah menggunakan strategi pembelajaran aktif Reading Aloud dan Teks Acak pada tanggal 05 Oktober 2015 mata pelajaran Qur'an Hadist kelas III semester I, materi surah At-Takatsur, dengan kegiatan sebagai berikut :guru menyampaikan materi surah AtTakatsur; guru mencontohkan membaca surah At-Takatsur dengan baik dan benar; lalu peserta didik diminta mengulangi bacaan tersebut; peserta didik secara bergantian membaca dengan keras setiap ayat surah At-Takatsur; membagi peserta menjadi beberapa kelompok; selanjutnya memberikan potongan kertas kecil yang berisi surah At-Takatsur; peserta didik menyusun surah At-Takatsur secara benar.

Strategi Ekspositori digunakan oleh saudara M. Rahmatullah pada tanggal 19 Oktober 2015 dengan mata pelajaran Ilmu Pengetahuan Sosial kelas III semester I,materi tentang mengenal arah mata angin. Rangkaian kegiatannya sebagai berikut : guru menjelaskan dan mempraktekkan materi pelajaran mengenai cara menentukan arah mata angin; peserta didik diajak ke lapangan untuk menetukan arah mata angin; peserta didik berbaris rapi dan megikuti perintah guru; selanjutnya dibagi menjadi beberapa kelompok; guru memberikan satu pertanyaan dan meminta peserta didik untuk menjawab secara bersama-sama tentang menentukan arah mata angin; peserta didik yang selesai menyerahkan tugasnya kepada guru dan didiskusikan; peserta didik mempresentasikan hasil diskusinya disaksikan oleh siswa lain dan guru.

\section{b. Kreativitas Mengajar dalam Penggunaan Media Pembelajaran}

Penyampaian materi pembelajaran tentunya dibutuhkan kreativitas yakni variasi dalam pembelajaran. Penggunaan media pembelajaran yang kreatif bisa jadi penunjang dalam proses belajar mengajar. Berdasarkan hasil observasi yang penulis lakukan di MI AL-Istiqamah Banjarmasin terdapat beberapa media pembelajaran yang menimbulkan keingintahuan siswa, mampu mengaktifkan siswa dan menarik perhatiannya.Penggunaan media pembelajaran oleh mahasiswa PPL II sebagai berikut:

\section{1) Annisa Widya Anggraeni}

Tanggal 15 Oktober 2015 Annisa menggunakan media pembelajaran jam dinding pada pembelajaran kelas $\mathrm{V}$ pada materi pengukuran waktu, jarak, dan kecepatan dalam pemecahan masalah. Media pembelajaran jam dinding sangat membantu guru untuk menjelaskan materi tentang pengukuran waktu, media ini mempermudah guru untuk menunjukkan kepada siswa mengenai keterangan waktu.

\section{2) Rahma Zuraida}

Tanggal 07 Oktober 2015 Rahma Zuraida menggunakan media beras, takaran beras, kantong plastik dan caption pada mata pelajaran Fikih mengenai tata cara zakat fitrah. Media ini digunakan untuk mendemontrasikan cara menghitung takaran beras untuk zakat fitrah. Media ini juga dapat merangsang keingintahuan peserta didik sehingga pembelajaran yang disampaikan menjadi lebih bermakna.

\section{3) Ainiah}

Tanggal 17 Oktober 2015 Ainiah menggunakan media gambar pada mata pelajaran Ilmu Pengetahuan Alam kelas IV semester I, materi tentang bagian-bagian telinga dan cara merawatnya. 


\section{4) Halimatus Sa'diah}

Tanggal 28 September 2015 Halimatus Sa'diah menggunakan media video pada mata pelajaran Akidah Akhlak kelas III ${ }^{\mathrm{a}}$ semester I, dengan materi tentang akhlak terpuji. Video pembelajaran termasuk media berbasis audio visual, video yang ditampilkan pada pertemuan ini berjudul kisah nabi ismail dan akhlak terpuji (Rendah Hati, Santun, Ikhlas, Dermawan).Melalui media ini pembelajaran Akidah Akhlak menjadi lebih bermakna, lebih menarik perhatian peserta didik dan membangkitkan motivasi peserta didik dalam proses belajar mengajar di kelas. Tanggal 06 Oktober 2015 Halimatus Sa'diah menggunakan media pembelajaran kartu pada mata pelajaran Ilmu Pengetahuan Sosial kelas III $^{\mathrm{a}}$ semester I, tentang materi memelihara lingkungan alam dan buatan. Media kartu ini terbuat dari karton berwarna merah yang dipotong menjadi beberapa bagian, isi dari kartu-kartu tersebut yaitu contoh lingkungan alam dan lingkungan buatan.

\section{5) Haryati}

Tanggal 06 Oktober 2015 Haryati menggunakan media puzzle pada mata pelajaran Akidah Akhlak kelas II $^{\mathrm{b}}$ semester I, materi tentang sholat lima waktu.Media puzzle ini berupa gerakan-gerakan sholat yang telah dibagi menjadi beberapa bagian, kemudian diacak terlebih dahulu dan dibagikan kepada setiap kelompok.Masing-masing kelompok diminta untuk mengurutkan gerakan sholat tersebut. Tanggal 22 Oktober 2015 Haryati menggunakan media gambar pada mata pelajaran IPA kelas II $^{\mathrm{b}}$ semester I, materi tentang tempat hidup makhluk hidup. Media gambar yang digunakan terbagi menjadi dua yaitu gambar tempat makhluk hidup dan kedua berupa gambar-gambar hewan. Melalui media gambar ini peserta didik sangat antusias selama mengikuti proses belajar mengajar di kelas. Media ini juga dapat meningkatkan aktivitas peserta didik melalu proses berpikir, mengingat, dan menempelkan gambar hewan sesuai dengan tempat hidupnya.

\section{6) Muhammad Rahmatullah}

Tanggal 19 Oktober 2015 Muhammad Rahmatullah menggunakan media kompas pada pelajaran IPS kelas III semester I, materi tentang mengenal arah mata angin. Melalui media ini siswa dapat mempraktikkan secara langsung bagaimana menentukan arah mata angin.

\section{c. Kreativitas Mengajar dalam Pemanfaatan Sumber Belajar}

Pemanfaatan sumber belajar akan memperkaya wawasan serta pengetahuan siswa dan dimaksudkan untuk memperoleh kemudahan dalam mendalami dan memahami pelajaran serta diharapkan siswa dapat aktif dalam mencari informasi sendiri melalui berbagai sumber belajar yang telah tersedia. Berdasarkan hasil observasi yang penulis lakukan di MI Al-Istiqamah, sumber belajar yang lebih banyak mereka gunakan adalah bahan ajar berupa buku pelajaran. Selain itu salah satu mahasiswa PPL II menggunakan sumber belajar berupa koran, dimanfaatkan oleh saudara Muhammad Mochran pada tanggal 21 Oktober 2015 di kelas VI semester I, pada pelajaran Bahasa Indonesia dengan materi memahami teks dengan membaca intensif dan membaca sekilas. Sumber belajar berupa lingkungan sekolah digunakan oleh Muhammad Rahmatullah tanggal 19 Oktober 2015 pada pelajaran IPS kelas III semester I, untuk materi mengenal arah mata angin. Siswa dibawa ke halaman sekolah untuk mempraktekkan arah mata angin berdasarkan petunjuk pada kompas.

\section{d. Faktor-faktor yang Mempengaruhi Kreativitas Mengajar Mahasiswa PPL II Jurusan PGMI}

\section{1) Faktor Mahasiswa PPL II}

a) Latar belakang pendidikan, mahasiswa PPL II Jurusan PGMI UIN Antasari Banjarmasin memiliki latar belakang lembaga pendidikan guru, hal ini lebih memudahkan mereka untuk menyesuaikan diri dengan lingkungan sekolah, karena sudah dibekali dengan seperangkat teori dan praktik serta pemahaman mengenai guru professional. Sehingga mahasiswa mampu mengimplementasikan pembelajaran yang telah mereka dapat pada saat melaksanakan PPL II. 
b) Pengalaman mengajar, mengajar merupakan kegiatan yang kompleks, mengajar mengandung arti memberikan informasi, mengajukan pertanyaan, menjelaskan, mendengar, mendorong dan sejumlah kegiatan lainnya.Calon guru bukan hanya dituntut untuk membuat siswanya belajar, melainkan juga dituntut untuk belajar mengajar untuk diri sendiri.Ia dituntut untuk melatih kemampuannya dalam merencanakan kegiatan pembelajaran, melaksanakannya, dan memantau perubahan-perubahan yang terjadi pada diri siswa.

Pengalaman belajar mengajar mahasiwa PPL II Jurusan PGMI Fakutas Tarbiyah dan Keguruan UIN Antasari Banjarmasin angakatan 2012 didapatkan melalui proses pembelajaran microteaching atau PPL I yang telah dilaksanakan pada bulan Juni 2015 Semester Genap Tahun Akademik 2014/2015 dan juga pada mata kuliah pembelajaran yang biasanya menerapkan praktik mengajar.

\section{2) Faktor Jumlah Peserta Didik}

Berdasarkan hasil observasi yang penulis lakukan, jumlah peserta didik di MI AlIstiqamah Banjarmasin pada tahun pelajaran 2014/2015 berjumlah 251 orang yang terdiri dari 135 laki-laki dan 116 perempuan. Adapun rincian peserta didik per kelas yaitu kelas I ada 54 orang, kelas II 56 orang, kelas III 35 orang, kelas IV 32 orang, kelas V 44 orang dan kelas VI ada 30 orang, sehingga total peserta didik adalah 251 orang. Berdasarkan hasil wawancara yang penulis lakukan pada hari sabtu tanggal 16 Oktober 2015, salah satu penghambat kreatitas mengajar di sekolah adalah karena terlalu banyak peserta didik di kelas. Hal ini sebagaimana disampaikan oleh saudari Amalia Sholeha, Haryati dan Ainah.

\section{3) Faktor Sumber Belajar}

MI Al Istiqamah mempunyai fasilitas dan sumber belajar yang cukup memadai untuk proses belajar mengajar. MI Al Istiqamah mempunyai 12 ruang belajar yang terdiri dari kelas I ada dua kelas, kelas II ada dua kelas, kelas III ada dua kelas, kelas IV ada dua kelas, kelas V ada dua kelas dan kelas VI ada dua kelas. Ruang belajar dilengkapi dengan meja, kursi, papan tulis, lemari buku, kipas angin untuk beberapa kelas, serta rak sepatu. Sumber belajar di MI Al Istiqamah Banjarmasin, berupa halaman sekolah, perpustakaan dan buku pelajaran.Perpustakaan memiliki koleksi buku yang cukup memadai tapi masih perlu adanya penambahan koleksi buku baru bagi peserta didik.

\section{4) Faktor Lingkungan Belajar yang Kondusif}

Letak bangunan sekolah dan keadaan lingkungan sekitar sekolah sangat mempengaruhi terhadap proses belajar mengajar. Suasana belajar yang nyaman dan aman akan memusatkan pikiran dan perhatian siswa kepada materi yang sedang dipelajarinya. Sebaliknya, apabila suasana belajar yang tidak nyaman, bising maka akan membuat konsentrasi belajar siswa terganggu. MI Al Istiqamah juga mempunyai lingkungan belajar yang kondusif. Karena letak bangunan sekolah MI Al Istiqamah yang berada jauh dari pasar, jalan raya, atau pabrik, tetapi sebaliknya malah berdekatan dengan mesjid. Bangunan fisik sekolah sebagian besar terbuat dari kayu, dan beberapa ruang kelas dilengkapi dengan kipas angin.

\section{B. Pembahasan}

\section{Kreativitas dalam Penggunaan Strategi /Metode Pembelajaran}

Strategi pembelajaran merupakan suatu rencana tindakan (rangkaian kegiatan) yang termasuk juga penggunaan metode dan pemanfaatan berbagai sumber daya/kekuatan dalam pembelajaran. Penggunaan strategi pembelajaran dapat merangsang kreativitas dan aktifitas peserta didik sehingga dapat membuat pembelajaran menjadi lebih efektif dan menyenangkan serta tujuan pembelajaran yang diharapkan dapat tercapai dengan optimal. Berdasarkan dari penyajian data sebelumnya penggunaan strategi pembelajaran yang diimplementasikan oleh mahasiswa PPL II saat praktik mengajar di kelas sangat beragam, hal ini terlihat dari banyaknya jenis strategi aktif yang digunakan seperti Crossword Puzzel,Make a Match, Index 
Card Match, Teams Game Tournament,Talking Stick, Everyone is A Teacher Here, Modeling the way, Card Short, The Power of Two, Contextual Teaching and Learning dan Ekspositori.

Metode pembelajaran digunakan untuk merealisasikan strategi yang telah ditetapkan.Dengan demikian, metode pembelajaran dalam rangkaian sistem pembelajaran memegang peran yang sangat penting. Keberhasilan implementasi strategi pembelajaran sangat tergantung pada cara guru menggunakan metode pembelajaran karena suatu strategi pembelajaran hanya mungkin dapat diimplementasikan melalui penggunaan metode pembelajaran.

Berdasarkan penyajian data yang telah penulis sajikan, penggunaan metode pembelajaran yang beragam telah dilakukan mahasiswa PPL II saat praktik mengajar di sekolah. Metode pembelajaran yang digunakan yaitu ceramah, tanya jawab dan demonstrasi. Penggunaan metode belajar juga dilakukan secara bervariasi artinya dalam proses belajar mengajar di kelas mereka memakai beberapa metode pembelajaran sekaligus. Pemilihan metode juga disesuaikan dengan materi pelajaran dan keadaan siswa di kelas. Penggunaan metode pembelajaran yang beragam akan membuat peserta didik lebih banyak melakukan kegiatan belajar sebab tidak hanya mendengarkan penjelasan guru, tetapi juga aktivitas lain seperti mengamati, melakukan, mendemonstrasikan, dan memerankan.

\section{Kreativitas Mengajar dalam Penggunaan Media Pembelajaran}

Penggunaan media pembelajaran saat proses belajar akan sangat membantu keefektifitasan proses pembelajaran dan penyampaian isi pelajaran tersebut. Media pembelajaran juga dapat membantu peserta didik meningkatkan pemahaman, penyajikan informasi akan lebih menarik sehingga menumbuhkan motivasi belajar, bahan pelajaran akan lebih bermakna, dan dapat mengatasi keterbatasan indera, ruang dan waktu. Berdasarkan data yang telah disajikan sebelumnya media pembelajaran yang digunakan oleh mahasiswa PPL II di MI Al-Istiqamah saat mengajar di kelas sangat bervariatif, media tersebut yaitu puzzle, caption,media gambar, alat peraga berupa kompas dan jam dinding, beras dan takarannya. Penggunaan media pembelajaran yang bervariasi ini menunjukkan bahwa mahasiswa PPL II telah bersikap kreatif dalam memilih media pada proses belajar mengajar di sekolah.

\section{Kreativitas Mengajar dalam Pemanfaatan Sumber Belajar}

Sumber belajar perlu didayagunakan seoptimal mungkin, dipelihara, dan disimpan dengan sebaik-baiknya. Kreativitas guru dan peserta didik perlu senantiasa ditingkatkan untuk membuat dan mengembangkan alat-alat pembelajaran serta alat peraga lain yang berguna bagi peningkatan kualitas pembelajaran. Kreativitas tersebut diperlukan, bukan semata-mata karena keterbatasan fasilitas dan dana dari pemerintah, tetapi merupakan kewajiban yang harus melekat pada setiap guru untuk berkreasi, berimprovisasi, berinisiatif dan inovatif.

Pemanfaatan sumber belajar oleh mahasiswa PPL II di MI Al-Istiqamah sebagian besar berupa buku pelajaran. Sumber belajar lainnya berupaperpustakaan tidak digunakan sewaktu proses pembelajaran, siswa datang ke peerpustakaan pada jam istirahat untuk meminjam buku atau membaca langsung di perpustakaan tersebut, itupun tidak banyak jika dibandingkan dengan jumlah seluruh siswa di madrasah tersebut. Lingkungan sekolah / halaman sekolah hanya sekali dimanfaatkan oleh mahasiswa PPL II sebagai sumber belajar, yakni Muhammad Rahmatullah yang mengajarkan tentang arah mata angin dengan media kompas. Sebenarnya lingkungan bisa dimanfaatkan sebagai sumber belajar yang paling efisien dan efektif untuk pembelajaran baik IPA, IPS, Bahasa Indonesia dan mata pelajaran lainnya. Pemanfaatan sumber belajar oleh mahasiswa PPL II di MI Al-Istiqamah bisa dikatakan kurang kreatif karena mereka lebih banyak memanfaatkan bahan ajar berupa buku pelajaran saja, sehingga hal ini perlu lebih ditingkatkan lagi.

\section{Faktor-faktor yang Mempengaruhi Kreativitas Mengajar}

a. Faktor Mahasiswa PPL II

1) Latar Belakang Pendidikan seorang caalon guru akan sangat mempengaruhi kreativitas 
mengajar di kelas, karena seorang guru harus menguasai dan memiliki kemampuan dalam memilih materi ajar yang akan disampaikan dalam pembelajaran dan memilih metode dan strategi pembelajaran yang tepat guna mencapai tujuan pembelajaran yang diharapkan. Dari penyajian data sebelumnya, Mahasiswa PPL II Jurusan PGMI UIN Antasari Banjarmasin memiliki latar belakang lembaga pendidikan guru, hal ini lebih memudahkan mereka untuk menyesuaikan diri dengan lingkungan sekolah, dan mengetahui serta mengaplikasikan pengetahuan yang dimilikinya ke dalam setiap pembelajaran yang dilakukannya.

2) Pengalaman mengajar mahasiwa PPL II Jurusan PGMI Fakutas Tarbiyah dan Keguruan IAIN Antasari Banjarmasin angakatan 2012 didapatkan melalui proses pembelajaran microteaching. Microteaching atau PPL I dilaksanakan pada tanggal 16 Juni 2015 Semester Genap Tahun Akademik 2014/2015 dan juga pada mata kuliah pembelajaran yang menjadi prasyarat untuk mengambil PPL. Microteaching bagi calon guru berfungsi untuk memberikan pengalaman mengajar yang nyata dan latihan sejumlah keterampilan dasar mengajar.Calon guru juga dapat mengembangkan keterampilan mengajarnya sebelum terjun ke lapangan, serta memberikan kesempatan kepada mahasiswa calon guru untuk menemukan dirinya sebagai calon guru.

\section{b) Faktor Jumlah Peserta Didik}

Kondisi siswa dalam belajar sangat berpengaruh terhadap kemampuan pendidik dalam menciptakan suasana belajar dan menggunakan metode dan strategi yang tepat, terutama jika jumlah siswa yang diajarkan sangat banyak.Hal ini disebabkan karena setiap siswa memiliki tingkat pemahaman yang berbeda dalam menangkap pelajaran. Selain itu kemampuan siswa dalam belajar juga mempengaruhi proses belajar.

Dari data yang penulis peroleh sebelumnya, jumlah siswa di MI Al Istiqamah sebanyak 251 orang, akan menjadi pertimbangan bagi guru dalam menentukan strategi/metode dan media yang digunakan dalam pembelajaran. Semakin banyak peserta didik di dalam kelas maka harus semakin kreatif guru tersebut memilih dan memanfaatkan metode, strategi, media serta sumber belajar yang harus digunakan dalam proses belajar mengajar guna mencapai tujuan yang yang diharapkan.

\section{c) Faktor Sumber Belajar}

Sumber belajar yang memadai merupakan salah satu faktor penunjang kreativitas mengajar seorang guru. Fasilitas dan sumber belajar itu antara lain laboratorium, pusat sumber belajar, dan perpustakaan, serta tenaga pengelola dan peningkatan kemampuan pengelolaannya. Dari pada itu, kreativitas guru dan peserta didik perlu senantiasa ditingkatkan untuk membuat dan mengembangkan alat-alat pembelajaran serta alat peraga lain yang berguna bagi peningkatan kualitas pembelajaran. Dari hasil penyajian data sebelumnya fasilitas dan sumber belajar yang ada disekolah sudah cukup untuk menunjang kreativitas mengajar mahasiswa PPL II.

\section{d) Faktor Lingkungan yang Kondusif}

Lingkungan sekolah yang nyaman, aman, dan tertib, optimisme dan harapan yang tinggi dari seluruh warga sekolah, kesehatan sekolah, serta kegiatan-kegiatan yang terpusat pada peserta didik merupakan iklim yang dapat membangkitkan nafsu, gairah dan semangat belajar. Iklim belajar yang kondusif merupakan tulang punggung dan faktor pendorong kreativitas mengajar yang dapat memberikan daya tarik tersendiri bagi proses belajar, sebaliknya iklim belaja yang kurang menyenangkan akan menimbulkan kejenuhan dan rasa bosan. MI Al Istiqamah mempunyai lingkungan belajar yang kondusif. Letak bangunan sekolah ini berada jauh dari pasar, jalan raya, atau pabrik. Bangunan fisik sekolah ini juga kokoh,ruang kelas lumayan besar dan di lengkapi dengan kipas angin dan ventilasi udara yang cukup sehingga membuat kelas terasa nyaman dan tidak panas. 


\section{PENUTUP}

1. Kreativitas mengajar mahasiswa PPL II UIN dapat dilihat dari bervariasinya strategi pembelajaran aktif yang digunakan, begitu juga dengan bervariasinya media sebagai alat bantu dalam pembelajaran. Sementara untuk sumber belajar, mahasiswa PPL II masih banyak hanya menggunakan sumber belajar berupa buku pelajaran.

2. Faktor-faktor yang mempengaruhi kreativitas mengajar mahasiswa PPL II, diantaranya faktor calon guru yang terdiri dari latar belakang pendidikan dan pengalaman belajar, faktor fasilitas dan sumber belajar, serta kondisi lingkungan yang kondusif.

\section{DAFTAR PUSTAKA}

Agung, Iskandar, Meningkatkan Kreativitas Pembelajaran bagi Guru. Jakarta: Bestari Buana Murni, 2010

Asmani, Jamal Ma'mur, Tips Menjadi Guru yang Inspiratif, Kreatif, dan Inovatif. Jogjakarta: DIVA Press, 2010

Asril, Zainal, Micro Teaching Disertai Dengan Pedoman Pengalaman Lapangan. Jakarta: Raja Grafindo Persada, 2007

Djamarah, Syaiful Bahri, Guru dan Anak Didik dalam Interaksi Edukatif. Jakarta: Rineka Cipta, 2010

Januari, Didik, dan Murtafi'atun, Trik A-Z Menjadi Guru Kreatif. Yogyakarta: Indoliterasi, 2015

Majid, Abdul, Pembelajaran Tematik Terpadu. Bandung: PT Remaja Rosdakarya, 2014

Mulyasa, H.E, Pengembangan dan Implementasi Kurikulum 2013. Bandung: PT Remaja Rosdakarya, 2013, Cet. Ke-3

Nasution, Teknologi Pendidikan. Jakarta: PT Bumi Angkasa, 2008

Nazir, Moh.,Metodologi Penelitian. Bogor: Ghalia Indonesia, 2011, Cet ke-7

Sanjaya, Wina, Strategi Pembelajaran Berorientasi Standar Proses Pendidikan. Jakarta: Listafariska Putra, 2008

Slameto, Belajar dan Faktor-faktor yang Mempengaruhinya. Jakarta: Rineka Cipta, 2003

Sugiyono, Metode Penelitian Pendidikan Pendekatan kuantitatif, Kualitatif, dan R\&D. Bandung: Alfabeta,2012

Sukmadinata, Nana Syaodih, Metode Penelitian. Bandung: PT. Remaja Roesdakarya, 2010

Supatian, Guru Sebagai Profesi. Jakarta: Hikayat, 2003

Talajan, Guntur, Menumbuhkan Kreativitas dan Prestasi Guru. Yogyakarta: LaksBang PRESSindo, 2012

Tim Redaksi Nuansa Aulia, Sistem Pendidikan Nasional (SISDIKNAS). Bandung: Bestari Murni, 2008.

Tim PPL, Pedoman Pelaksanaan PPL Fakultas Tarbiyah dan Keguruan, IAIN Antasari Banjarmasin, 2012.

Uno, Hamzah, Model Pembelajaran Menciptakan Proses Pembelajaran yang Kreatif dan Efektif. Jakarta: Bumi Aksara, 2008

Wijaya, Cece, dan A. Tabrani Rusyan, Kemampuan Dasar Guru dalam Proses Belajar Mengajar. Bandung: Remaja Rosda Karya. 
AL-ADZKA, Jurnal Ilmiah Pendidikan Guru Madrasah Ibtidaiyah

Volume VIII, Nomor 01, Hal (61-75)

Juni 2018 